\title{
Determinants of success and constraints of integrated ridesharing in rural areas
}

\author{
Jonas Harz *, Carsten Sommer \\ University of Kassel, Chair of Transportation Planning and Traffic Systems, Mönchebergstraße 7, 34125 Kassel, Germany
}

\section{A R T I C L E I N F O}

\section{Keywords:}

Ridesharing

Mobility as a service

Rural areas

Public transportation

\begin{abstract}
A B S T R A C T
Ridesharing is often seen as a possibility to increase the mobility of citizens in rural areas, especially in connection with existing public transport. Two platforms were examined and evaluated in the research project "GetMobil", which focuses on the barriers and potentials in relation to the effects achieved. This was done with several surveys, analysis of usage data and expert interviews. The research showed that one common feature of both platforms was the low number of successfully completed rides. The question arising from this is: how should a ridesharing platform be designed in order to achieve a high proportion of matches between ridesharing offers and requests, motivate as many people as possible to participate actively and increase the mobility of residents in the region. Based on the examinations, recommendations were compiled for implementing ridesharing services.
\end{abstract}

\section{Introduction}

Inhabitants of rural areas exhibit mobility behavior vastly different from that of urban dwellers. Private cars remain the primary means of transportation (Pucher and Renne, 2005). According to the study "Mobility in Germany 2017", 71 \% of all trips in rural areas in Germany feature private car use (Follmer and Gruschwitz, 2019). In contrast, public transport in those areas is typically geared to school transport and rarely provides regular service. Ongoing demographic changes and an ageing population pose additional challenges to public transport in rural areas (Osti, 2010). The decline in student numbers, in particular, leads to decreasing income, while costs remain unchanged (Steinrück and Küpper, 2010). As a result, mobility options (and thus the attainability of relevant destinations in rural regions) decrease, directly influencing chances of social participation. Residents without access to a car are particularly affected, as they are then dependent on public transport (between 10 and $15 \%$ of the households in rural areas). In total, only 4 $\%$ of all trips undertaken in rural areas are covered by public transport (Follmer and Gruschwitz, 2019).

In order to improve public transport services in these areas and thus increase the mobility options of people without access to a car, various new transport services that can be summarized under the term "mobility as a service" are being tested. Due to the dominance of the car and the fact that the average car is occupied by only 1.5 people (see Follmer and Gruschwitz, 2019), ridesharing in particular is considered to have the potential to increase mobility options in rural areas. It should be noted, however, that due to the low population density (Petersen, 2016) and correlating low traffic volumes in relation to the length of the road network, the probability that travel offers and ride-sharing requests take place in the same spatial corridor at the same time ("matching probability") is significantly lower in rural areas than in urban areas (see Sommer et al., 2016).

Therefore, for a ridesharing platform the question arises as to how it can be designed to:

a) achieve a high percentage of matchings between ride offers and ridesharing requests,

b) motivate as many people as possible to actively participate and

c) increase the mobility of the area's inhabitants.

To answer these questions, various surveys and studies were carried out in the research project "GetMobil - Geteilte und vernetzte Mobilitätsdienstleistungen" (GetMobil - Shared and Linked Mobility Services) that dealt with the potentials, obstacles, and effects of ridesharing in rural areas on the basis of two field projects. The project was funded by the German Federal Ministry of Education and Research and was carried out jointly by three chairs of the University of Kassel and Nordhessischer Verkehrsverbund (Transport Association of Northern Hesse, NVV) from 2015 to 2018. This article summarizes the results from a traffic-planning point of view, including the underlying methods of the project.

\footnotetext{
* Corresponding author.

E-mail address: jonas.harz@uni-kassel.de (J. Harz).
} 


\section{Subject matter}

\subsection{State of research}

Various types of private and partly-commercial ridesharing systems are summarized under the term "ridesharing" in public discussions but also among experts. Chan and Shaheen (2012) propose a ridesharing definition that includes private carpooling among family and friends, organization-based car- and vanpooling via a membership or a web service as well as "ad-hoc" ridesharing (for example hitchhiking).

For this article, however, the definition for ridesharing provided by the German Federal Ministry of Transport and Digital Infrastructure (2016) is used, which concentrates on the segment of organizationbased car- and vanpooling: "Ridesharing is understood to encompass publicly accessible systems in which free places in private cars are made available to third parties, usually via an internet-based platform".

The concept of ridesharing has been tested and implemented in various forms, with regard to different user groups as well as different spatial structures. A broad overview of the classification of existing ridesharing services is given by Furuhata et al. (2013). This classification points out that the predominant part of ridesharing platforms offers long-distance ridesharing or ridesharing for commuters. In contrast, dynamic real time ridesharing services analyzed in this paper are a minority. Furthermore, most ridesharing services and the related research concentrate on urban areas (Çetin, 2017; Stiglic et al., 2016), whereas the literature for ridesharing in rural areas is very sparse.

Especially in German-speaking countries, various possibilities have been tested in recent years to establish ridesharing in rural areas. These range from informal concepts such as the so-called "ridesharing benches" (Becker et al., 2019), to projects that try to integrate ridesharing into existing public transport structures. One of the oldest trials of ridesharing in a rural environment started in 1985 in Cloppenburg and Bad Berleburg (Germany). The project "Nimm mit - steig zu" gave out badges for drivers and passengers and built specific pick up locations. (Wegmann, 2007)

In Switzerland, the project "CARLOS" tested ridesharing in a rural context for three years between 2003 and 2005 in the region of Burgdorf. Eleven call boxes were installed in seven municipalities inside the region, where drivers could pick up passengers. These call boxes were equipped with an LED-display which displayed the destination point of potential passengers. (Artho et al., 2005; Wegmann, 2007) A successor of CARLOS is "Taxito", which operates in several regions of Switzland since 2015. The ridesharing requests are sent to the call boxes via a mobile app or text message and are then displayed. A registration for taking part is not necessary, neither for the drivers or the passengers. (Thao et al., 2021)

Beside residents, also other user groups are taken into consideration for ridesharing. The Italian island of Elba is establishing the so-called "Shared Use Mobility Agency" which will coordinate different shared mobility services on the island, including ridesharing. The proposed app will have the ability to share trips and allow hitchhiking for spontaneous rides. In addition, users will have the possibility to share taxi trips. In contrast to other concepts, the app is especially geared towards tourists due to the high seasonal mobility demand of tourists on the island. (Ambrosino, 2018)

In recent years, ridesharing benches became very popular in Germany and have been installed by many local authorities. Since the first bench was built in 2014 in the town Speicher (Rhineland Palatinate), the number of benches in Rhineland Palatinate increased to 288. In Hesse, there are currently 136 benches in operation. (Roubicek, 2019)

To this end, benches are set up in public spaces, which are usually equipped with interchangeable destination or direction signs. Sitting on the bench signals the wish for a ride. The sign setup shows passing drivers the desired direction or destination. Due to the low costs for a bench including the signs, the threshold for such systems is usually low, likely adding to their popularity. Ridesharing benches are an attempt to provide informal private ridesharing with a degree of organization. However, since the provision of shared rides is not documented, no conclusion can yet be drawn on the frequency of shared rides and the resulting effects.

In several rural municipalities in all over France, there is a mobile application-supported service similar in approach to the ridesharing benches, which is operated under the name RezoPouce. Municipalities and the RezoPouce association locate hitchhiking spots based on different criteria, like the presence of a frequently used road or residential zones nearby. To participate, drivers and passengers need to register in advance. The mobile application is not necessary to organize rides but it helps to give the user information about the location of hitchhiking spots, makes ride requests and offers visible and gives the passenger information about the driver's position. In 2019, RezoPouce operated in 1305 municipalities in France. (SMARTA, 2019)

It should be noted that ridesharing alone can not provide the basis for people's mobility because of the prevalent uncertainty for passengers of getting a matching ride. Only when combined with public transport, it can offer an alternative to the private car and thus generate the desired positive effects. This is usually realized by integrating the various services into the existing public transport network. Integration can take place at different levels and to different depths and extents:

- linking a transport offer with public transport,

- distribution linkage,

- tariff linkage,

- linking in the sphere of information and communication (see Sommer et al., 2016).

At the end of the project (June 2018), Germany hosted three ridesharing systems, which were linked to public transport in different ways: Mobilfalt, Garantiert mobil! and flinc. The type and level of integration of the three systems is shown in Table 1.

Within the framework of the GetMobil research project, the two ridesharing platforms Mobilfalt and Flinc were examined in greater detail. Both platforms are or were active in rural areas. The focus of the research was on the constraints and capabilities of the platforms with regard to the impacts achieved.

Table 1

Overview of the type and level of integration into the public transport system of Mobilfalt, Garantiert mobil! and flinc.

\begin{tabular}{|c|c|c|c|c|}
\hline System & Service offered & Distribution & Tariff & Communication \\
\hline Mobilfalt & $\begin{array}{l}\text { complete } \\
\text { (Ride offering } \\
\text { and sharing as } \\
\text { a supplement } \\
\text { to classic } \\
\text { public } \\
\text { transport, } \\
\text { "mobility } \\
\text { guarantee") }\end{array}$ & $\begin{array}{l}\text { partial } \\
\text { (electronic } \\
\text { ticket for } \\
\text { direct rides } \\
\text { with } \\
\text { Mobilfalt) }\end{array}$ & $\begin{array}{l}\text { partial } \\
\text { (one price } \\
\text { for direct } \\
\text { trips with } \\
\text { Mobilfalt) }\end{array}$ & $\begin{array}{l}\text { complete } \\
\text { (integrated in } \\
\text { schedule) }\end{array}$ \\
\hline $\begin{array}{c}\text { Garantiert } \\
\text { mobil! }\end{array}$ & $\begin{array}{l}\text { complete } \\
\text { (Ridesharing } \\
\text { as a } \\
\text { supplement to } \\
\text { classic public } \\
\text { transport, } \\
\text { "mobility } \\
\text { guarantee") }\end{array}$ & $\begin{array}{l}\text { complete } \\
\text { (electronic } \\
\text { ticket) }\end{array}$ & $\begin{array}{l}\text { complete } \\
\text { (integrated } \\
\text { in RMV- } \\
\text { tariff, } \\
\text { specific } \\
\text { surcharges) }\end{array}$ & $\begin{array}{l}\text { complete } \\
\text { (integrated in } \\
\text { schedule) }\end{array}$ \\
\hline flinc & $\begin{array}{l}\text { partial } \\
\text { (through } \\
\text { cooperation } \\
\text { with transport } \\
\text { companies) }\end{array}$ & none & none & $\begin{array}{l}\text { complete } \\
\text { (integrated in } \\
\text { flinc-/ schedule) }\end{array}$ \\
\hline
\end{tabular}




\subsection{Mobilfalt}

In order to improve public transportation, NVV introduced a service called "Mobilfalt" in 2013, which integrates ridesharing into the existing public transport system. At present Mobilfalt is offered in five municipalities in North Hesse (Witzenhausen, Großalmerode, Sontra, Herleshausen and Nentershausen). Mobilfalt supplements the existing bus timetable with rides as required, so that overall an hourly frequency is created on weekdays between 5 AM and midnight and on Sundays between $8 \mathrm{AM}$ and midnight. On-demand rides start and end at public transport stops and connect the villages with the nearest local centre. Demand-driven rides are only carried out if passengers have booked them at least one hour before the ride. A special feature of Mobilfalt is that demand-driven rides can also be carried out by private drivers. This enables drivers to enter their private rides into the Mobilfalt system. They can choose between a one-time ride and a recurring offer. In the case of a matched ride request and offer, the driver is informed via text message or e-mail and can then accept or reject the ride. If no private driver can be found for a reservation, a so-called mobility guarantee applies, meaning that the ride is covered by a taxi. Both ridesharing requests and offers can be entered either by telephone or using an online booking system (see Fig. 1). Passengers pay the public transport fare plus a one Euro surcharge for a Mobilfalt trip. Drivers receive a reimbursement of 0.30 Euro per kilometer for private rides ${ }^{1}$.

Since the introduction of Mobilfalt, the number of passengers has risen steadily. For many inhabitants in the pilot area, Mobilfalt is an important part of their daily mobility. An earlier survey during the implementation of Mobilfalt showed that $59 \%$ of rides occurred because passengers commuted to or from work and in $21 \%$ of the cases people were running errands. However, there is a lack of private transport offers and active drivers in Mobilfalt. As a result, before the start of the project, approx. $99 \%$ of the rides were ultimately carried out by taxi and only approx. 20 drivers were active in Mobilfalt (Sommer and Schmitt, 2015).

\subsection{Garantiert mobil!}

A similar but even more integrated approach is "Garantiert mobil!" in the Odenwald district in southern Hesse (Germany) which has been in service since 2017. Under this brand, regular public transportation (fixed and flexible bus service), ridesharing and taxis (called "TaxOMobil") are combined and offer transportation with the same base tariff of the local transport association. Registered private and commercial drivers can offer rides, either with fixed or flexible departure times as well as recurring offers. Private drivers get a compensation of $0.12 €$ per kilometer whereas commercial drivers can get a higher amount which is negotiated with the local transport association. If a passenger books a ride and there is neither a regular bus service nor a ridesharing offer, the ride can be executed by TaxOMobil with a surcharge based on the distance. This surcharge can be reduced on defined routes or times by sponsors such as companies or municipalities. The backend is based on the same software as the backend of Mobilfalt but it has been upgraded for the additional requirements of Garantiert mobil!. (Krämer et al., 2019)

\subsection{Flinc}

"Flinc", with its ridesharing portal of the same name, was one of the largest providers of ridesharing services for short-distance routes until the company ceased operations at the end of 2018. Users were able to post both travel offers and ridesharing requests on the platform with precise addresses. There were no spatial or temporal restrictions. Thus,

\footnotetext{
${ }^{1}$ A higher reimbursement for drivers has been evaluated (doubling from 0.30 $€$ to $0.60 €$ per kilometer), but significantly more people were opposed to it in comparison to the existing reimbursement of $0.30 €$. (Daskalakis (2019).)
}

the algorithm used made it possible to compare travel offers with travel requests that only had sections of the trip in common or for which smaller detours were necessary. Thus, flinc differed from other ridesharing portals, which are usually used for long-distance journeys and allow stops on the driver's route only by explicit input from the driver.

One of flinc's unique characteristics was that it entered into cooperation agreements with companies, universities, administrative districts and public transport authorities within the framework of mobility management. This form of cooperation included so-called "in-house" ridesharing networks, which allowed the advertising of offers and requests for ridesharing in a familiar area closed off from the rest of the ridesharing portal. In some cases, additional links to local public transport were created. For example, in the cooperation project "PubliRide" (see Leuzinger and Meyer, 2017) public transport rides were displayed in the ridesharing portal and vice versa and flinc travel offers in the public transport timetable (see Fig. 2).

The user-analysis of the number of three flinc ridesharing networks showed that even fewer rides were successfully carried out than with Mobilfalt. Only $0.2 \%$ (PubliRide Baden) and $1.4 \%$ (Mitfahrnetzwerk Universität Hohenheim) of the travel and ride offers could finally be arranged. The traffic effects of flinc were therefore very low. (Harz and Sommer, 2019)

\section{Methodology}

\subsection{Overview of methodology}

Within the project, various empirical and data-based methods were used to determine the potential, constraints and effects of the two examined ridesharing systems. The introduction of various measures for Mobilfalt in the context of a field experiment divides the project into an ex-ante and an ex-post state. Results from a Mobilfalt user survey, a household survey and two potential analyses were used in the ex-ante state to develop proposals for measures for the field experiment. The effects were assessed on the basis of a second Mobilfalt user survey and the evaluation of key figures of the Mobilfalt usage data. The core results of the estimated effects of the field experiment, as well as from the potential analyses and a system analysis by flinc, were summarized, and used to develop recommendations. Fig. 3 illustrates the synergy of the individual methodical steps.

\subsection{Evaluation of Mobilfalt usage data}

Thanks to the cooperation with the NVV, it was possible to get direct access to the resulting usage data from the booking system. Descriptive analyses allowed the continuous determination and monitoring of parameters such as the proportion of ridesharing trips and the number of private drivers during the project period.

\subsection{Ex-ante household survey of mobility behavior}

A household survey was carried out to determine mobility behaviour in the Mobilfalt research area. The sample size was selected based on two features: transport volume and modal split. For the research area with around 25,000 inhabitants, 1,000 respondents are needed to determine the transport volume with a confidence level of $99 \%$ and a confidence interval of $+/-4 \%$ and the modal split with a confidence level of $+/-2 \%$. Households were chosen and contacted randomly based on public telephone registers.

A total of 1,017 persons from 804 households in the municipalities of Witzenhausen, Sontra, Herleshausen and Nentershausen were surveyed about their trips and out-of-home activities on the reference date using a computer-assisted telephone interview (CATI). This corresponds to a take-up rate of $14 \%$. The results of the survey corresponded to the core elements of the surveys "Mobilität in Deutschland" (Mobility in Germany, MiD) and Mobilität in Städten (Mobility in Cities, SrV), with 
Fahrtwunsch buchen

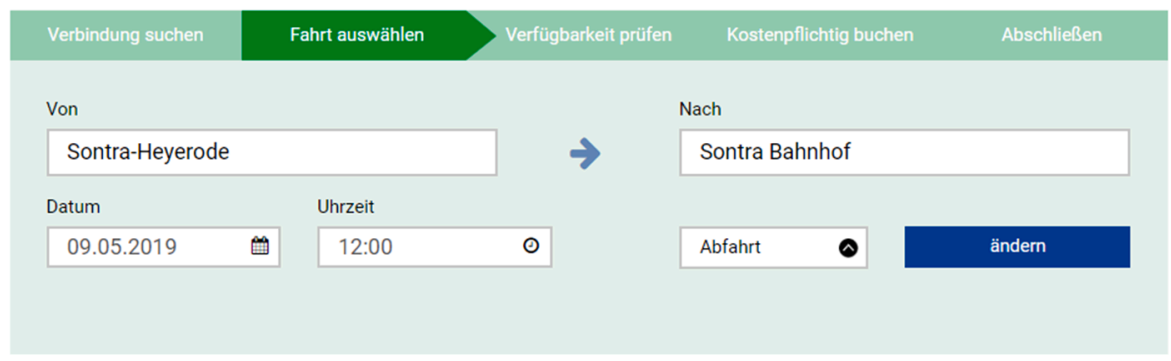

Bitte wählen Sie Ihre passende Fahrt

\begin{tabular}{|c|c|c|c|c|}
\hline \multicolumn{5}{|c|}{ (1) Früher } \\
\hline Haltestelle & Datum & Zeit & Verkehrsmittel & \\
\hline $\begin{array}{l}\text { Sontra-Heyerode } \\
\theta \text { Sontra Bahnhof }\end{array}$ & 09.05 .2019 & $\begin{array}{l}\text { ab 11:00 } \\
\text { an 11:15 }\end{array}$ & $\theta$ & auswählen \\
\hline $\begin{array}{l}\text { Sontra-Heyerode } \\
\theta \text { Sontra Bahnhof }\end{array}$ & 09.05 .2019 & $\begin{array}{l}\text { ab 12:00 } \\
\text { an 12:15 }\end{array}$ & $\theta$ & auswählen \\
\hline $\begin{array}{l}\text { Sontra-Heyerode } \\
\theta \text { Sontra Bahnhof }\end{array}$ & 09.05 .2019 & $\begin{array}{l}\text { ab 12:41 } \\
\text { an 13:00 }\end{array}$ & Bus & \\
\hline $\begin{array}{l}\text { Sontra-Heyerode } \\
\theta \text { Sontra Bahnhof }\end{array}$ & 09.05 .2019 & $\begin{array}{l}\text { ab } 14: 24 \\
\text { an } 14: 40\end{array}$ & Bบ & \\
\hline $\begin{array}{l}\text { Sontra-Heyerode } \\
\theta \text { Sontra Bahnhof }\end{array}$ & 09.05 .2019 & $\begin{array}{l}\text { ab 15:00 } \\
\text { an 15:15 }\end{array}$ & $\theta$ & wählen \\
\hline & & & & \\
\hline
\end{tabular}

Fig. 1. Online booking system of Mobilfalt (www.mobilfalt.de).

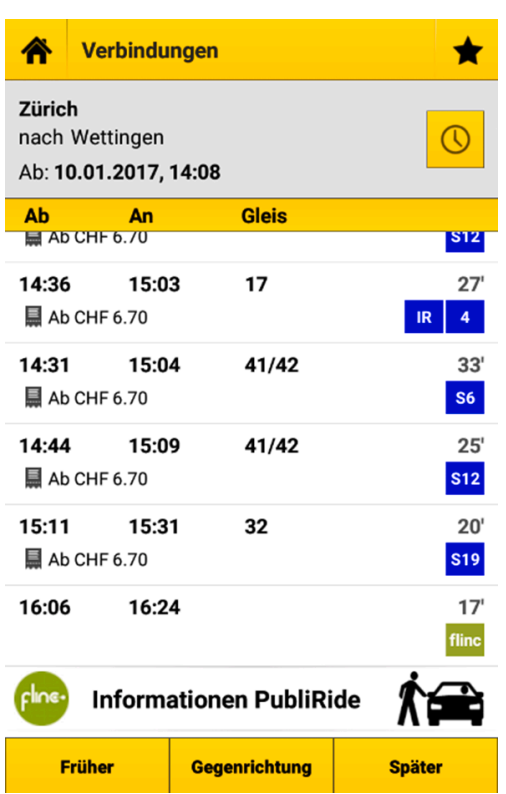

Fig. 2. App of Postauto AG with integration of flinc.

additional specific questions being asked on sharing or offering rides. The sample selection was random; nevertheless, the data is partly distorted. Inhabitants under 50 years of age and household with more than two members are especially underrepresented. This can partly be explained with the chosen method of using public telephone registers that usually do not contain numbers of mobile telephones. Random digit dialing was considered, but rejected due to the high screening effort to reach households inside the research area. Because of the obvious distortions, the data was extrapolated and weighted on gender, age groups and household size.

The survey served various research objectives objectives. Firth the number and pattern of potential drivers and passengers of Mobilfalt were to be estimated. Furthermore, possible new destinations and stops as well as the potential for Mobilfalt rides on the different routes were to be determined. The data collected by the surveys was enriched with further external data for the analyses. Spatial information such as stop data or routes of car trips were included.

\subsection{Potential analyses}

Using the data obtained in the household survey, two potential analyses for Mobilfalt were conducted, one at the

- level of persons involved (drivers and passengers) and

- one regarding traffic volume (car trips)

In the potential analysis at individual/user level, the potential for participation as a driver or passenger in Mobilfalt in the total population of the study area was determined with the help of a model developed specifically for the project. Influencing factors of the model were participants' transport choice options (transportation accessibility), their experiences with travelling or taking along people outside their own household, knowledge of Mobilfalt as well as attitudes and personality traits regarding ridesharing or offering rides. The features of the influencing factors were transformed into metric values according to their influence on the potential. For the attitudes and personality factors, the features were determined with the help of a principal component analysis. The influence of each influencing factor on the total potential is controlled by an individual weighting factor. The weighting factors were 


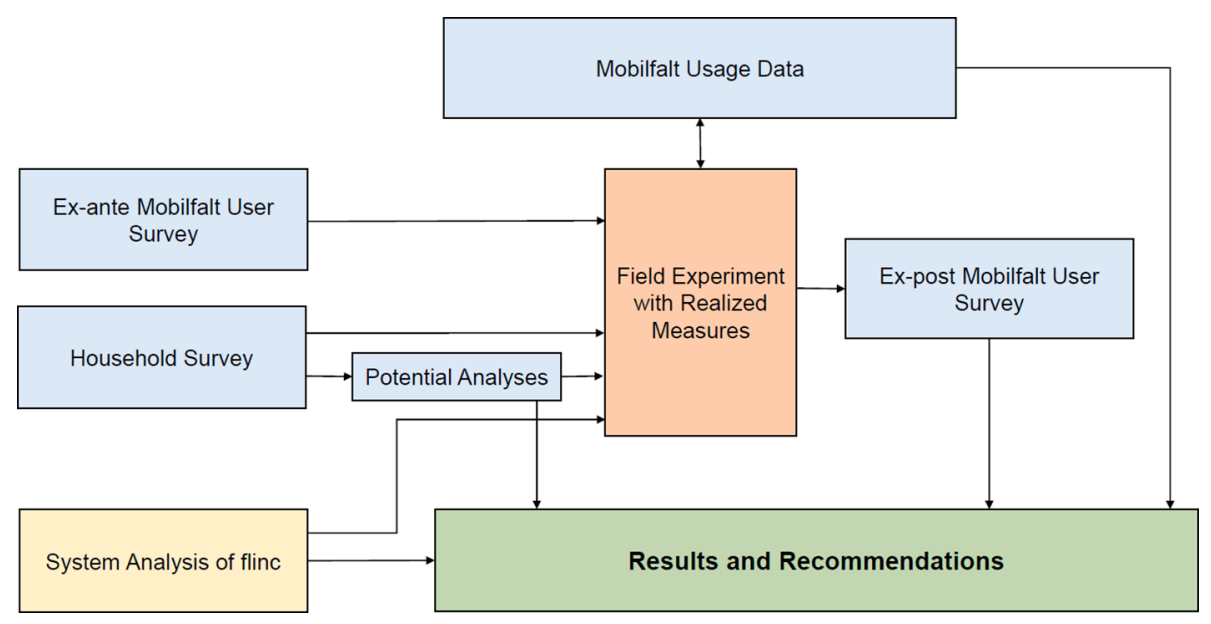

Fig. 3. Overview of the interaction of the different methods.

determined in such a way that the extent of objectivity and reliability of each factor is considered. With increasing objectivity, individual factors have more influence on the total potential. The calculated potential score $\mathrm{s}$ is a value between 0 (no potential) and 100 (maximum potential). The model permits a comparison of the potential strength with other variables such as socio-demographic or mobility behavior characteristics by classifying the potential score into potential groups:

$\mathrm{s}<10$ : no potential

$10 \leq \mathrm{s}<40$ : low potential

$40 \leq \mathrm{s}<70$ : medium potential

$70 \leq \mathrm{s}:$ high potential

Therefore, potential users could be identified more precisely. Exemplarily, this is shown in Fig. 4 for sociodemographic stages of life and in Fig. 6 for the frequency of internet usage in relation to the potential score to participate as a driver. In both cases a one-way ANOVA was performed to compare the potential score and the dependent variables. For both cases there was a statistically significant difference between the groups:

- Sociodemographic stages of life: $F(8,25147)=[100.072], p=0.00$

- Internet usage: $\mathrm{F}(4,25103)=[284.447], \mathrm{p}=0.00$

In Tables 2 and 3 the mean values and standard deviation for both dependent variables are summarized. For a more detailed description of the model, see Sommer and Harz (2018).

The potential analysis at the traffic volume level aimed at determining the spatial and temporal potential of privately offered rides for the Mobilfalt routes. To this end, all trips of the motorized private transport (MPT) in the study area were first spatially intersected with the possible Mobilfalt routes. For the route sections with the greatest potential, an additional temporal linkage of the Mobilfalt offer with the MPT trips determined in the household survey was carried out. This was necessary, since not all districts offer Mobilfalt all day. For existing bus services, Mobilfalt is often only an additional option in times of low

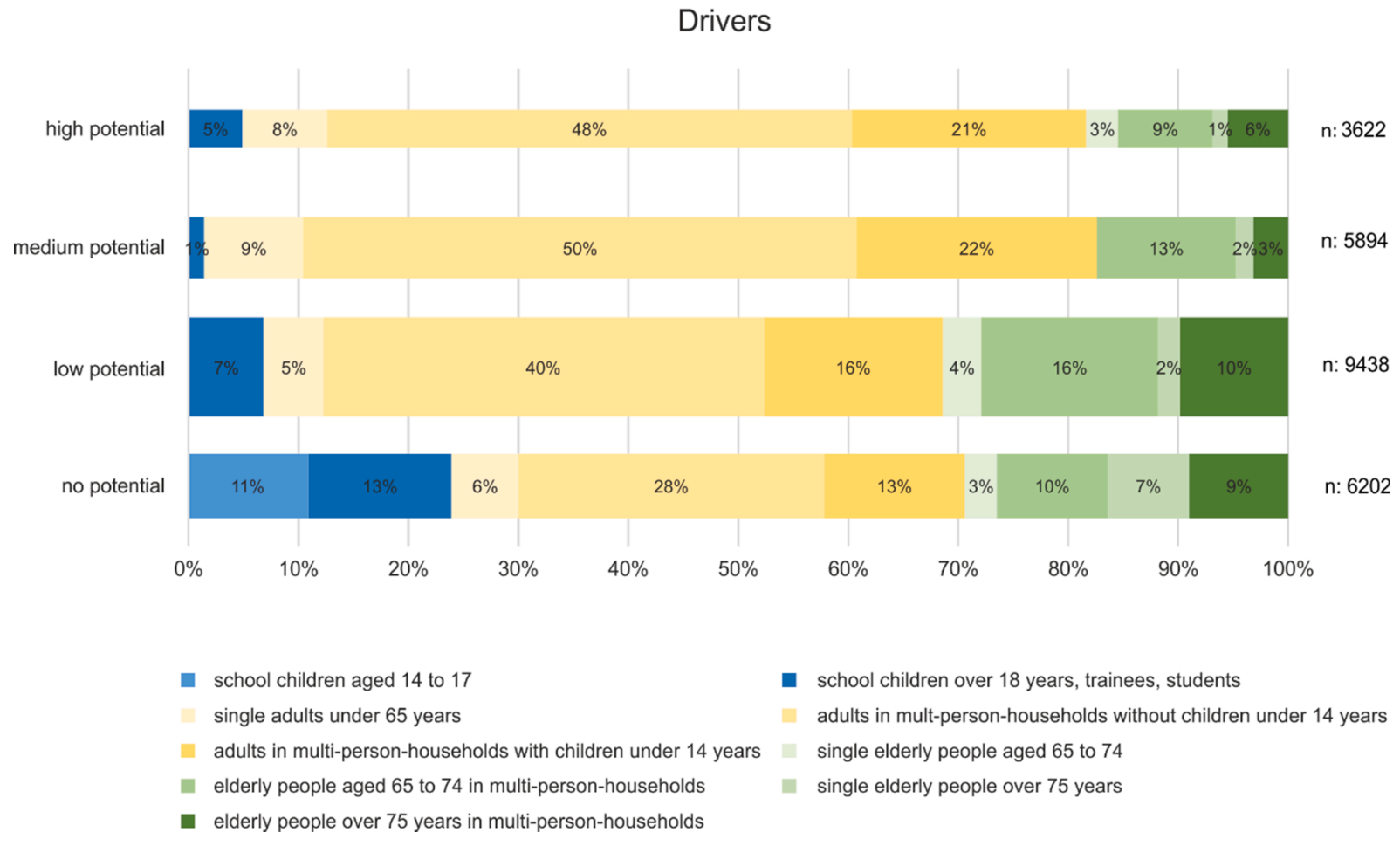

Fig. 4. Allocation of the potential groups (drivers) into sociodemographic stages of life. Source: Sommer and Harz (2018). 
Table 2

Mean and standard deviations of the potential score for different sociodemographic stages of life.

\begin{tabular}{|c|c|c|c|}
\hline & $\mathrm{n}$ & mean & $\begin{array}{l}\text { standard } \\
\text { deviation }\end{array}$ \\
\hline school children ages 14 to 17 & 1,174 & 28.42 & 24.78 \\
\hline $\begin{array}{l}\text { school children over } 18 \text { years, trainees, } \\
\text { students }\end{array}$ & 2,027 & 30.28 & 24.99 \\
\hline single adults under 65 years & 1,662 & 37.30 & 29.25 \\
\hline $\begin{array}{l}\text { adults in multi-person-households without } \\
\text { children under } 14 \text { years }\end{array}$ & 9,523 & 36.92 & 28.05 \\
\hline $\begin{array}{l}\text { adults in multi-person-households with } \\
\text { children under } 14 \text { years }\end{array}$ & 4,150 & 36.58 & 28.69 \\
\hline single elderly people ages 65 to 74 & 647 & 26.00 & 25.40 \\
\hline $\begin{array}{l}\text { elderly people aged } 65 \text { to } 74 \text { in multi-person- } \\
\text { households }\end{array}$ & 3,019 & 30.95 & 26.10 \\
\hline single elderly people over 75 years & 1,008 & 21.87 & 24.39 \\
\hline $\begin{array}{l}\text { elderly people over } 75 \text { years in multi-person- } \\
\text { households }\end{array}$ & 1,946 & 24.02 & 25.16 \\
\hline total & 25,156 & 33.36 & 27.63 \\
\hline
\end{tabular}

Table 3

Mean and standard deviations of the potential score for different frequencies of internet usage.

\begin{tabular}{llll}
\hline & $\mathrm{n}$ & mean & standard deviation \\
\hline daily & 16,343 & 36.84 & 27.73 \\
several times per week & 2,856 & 32.78 & 28.43 \\
few times per month & 1,182 & 29.15 & 28.35 \\
less often & 530 & 36.01 & 27.28 \\
never & 4,198 & 21.32 & 22.55 \\
total & 25,108 & 33.40 & 27.64 \\
\hline
\end{tabular}

demand (e.g. off-hours on weekdays or weekends). The results of the temporal linkage showed the proportion of MPT trips that could theoretically have been offered by Mobilfalt within the offer period. Fig. 5 exemplifies the intersection of the time variation curve of MPT routes between Sontra and Hornel with the Mobilfalt offer for this route.

\subsection{Ex-ante and ex-post Mobilfalt user surveys}

The first user survey in the project had the primary objective of having possible measures and improvements in Mobilfalt evaluated by the users. In addition, the satisfaction with Mobilfalt in its initial state was assessed. Based on the ex-post user survey (as well as the usage data), an evaluation of the effects of the measures implemented in the field experiment was carried out. In addition, the interviewed users were asked to rate Mobilfalt in its ex-post state. Both surveys were intended as a complete survey of all active Mobilfalt users. In the first survey, 191 active Mobilfalt users could be interviewed, which amounts to a $56 \%$ coverage. The second survey achieved a $39 \%$ coverage with 200 surveyed users.

\subsection{Field experiment}

Specific measures were proposed based on the results of the household survey, the potential analyses and the ex-ante user survey. Four measures were implemented during the project period:

- A new user interface for the Mobilfalt booking system,

- a publicity campaign to recruit new drivers,

- partial integration of Mobilfalt into the existing public transport tariff and distinction between private rides and rides with the mobility guarantee,

- Flexibilization of the offer in regard to time by means of a 10-minute interval in the pilot room in Witzenhausen.

\subsection{System analysis of flinc}

Against the background of the deficits of Mobilfalt and the question of how to motivate more people to actively offer rides, a system analysis was carried out to investigate to what extent comparable ridesharing services reveal possibilities for improvement. Through the consistent use of the possibilities offered by information and communication technology, flinc stood out from other ridesharing portals. Therefore, a threepart system analysis was carried out. This was divided into the following analytical steps:

- Analysis of the flinc user interface with regard to design and functional aspects.

- Analysis of the user behavior of flinc members on the basis of three ridesharing networks with the help of a web scraping procedure. ${ }^{2}$

- Expert survey on cooperation projects with flinc in rural areas. (Benz and Kepper, 2019)

The results of the analysis of the user interface were also incorporated into the ongoing development of the Mobilfalt booking system (measure "new user interface").

\section{Results and recommendations}

\subsection{Reliability}

An essential difference between Mobilfalt and flinc is the handling of situations in which no private driver can be found or a trip is cancelled. With Mobilfalt, a mobility guarantee applies in these situations, whereby the passengers can rely on being transported. This reliability is not guaranteed by flinc: The passengers must themselves organize alternatives if a journey is cancelled or if no driver is available. As described, it is or was the rule for both platforms that no private driver could be found (see sections 2.2 and 2.3). Thus, if there is no significant increase in the number of matches between travel offers and requests, a ridesharing system cannot provide a reliable service.

It turned out that the mobility guarantee implemented by Mobilfalt is a very important system feature for ridesharing in rural areas. The lack of reliability with flinc was seen in expert discussions as a decisive reason for the very low rate of usage. Only a mobility guarantee can ensure an improvement of the transport infrastructure and the reliability necessary to increase the mobility options of the inhabitants of rural areas.

\subsection{Degrees of freedom in travel offers}

The strong integration of Mobilfalt into the existing public transport system means that travel offers and ridesharing requests are limited to certain routes and departure times. While this is usually not a problem for passengers as they are familiar with the public transport system, it is a significant barrier for (potential) drivers to offer rides. Overall, a ridesharing system must be designed so that (potential) drivers can use the system easily, quickly and without cognitive stress. It is also important that the system is tailored to the driver's level of experience. This means, for instance, that drivers can freely determine the route and departure time for an offered trip. In the Mobilfalt ex-ante user survey, it became apparent that a majority of active drivers would offer more trips with Mobilfalt if they were free to choose their time and route. The analysis of the potential of Mobilfalt routes showed that especially in the periods with the highest car traffic volume there is no Mobilfalt offer and therefore rides could not be arranged (cf. Section 3.4). In the pilot area Witzenhausen, therefore, from October 2017 onwards a more flexible

\footnotetext{
${ }^{2}$ Web Scraping describes a process in which an algorithm is used to extract and process large amounts of data from the Internet.
} 


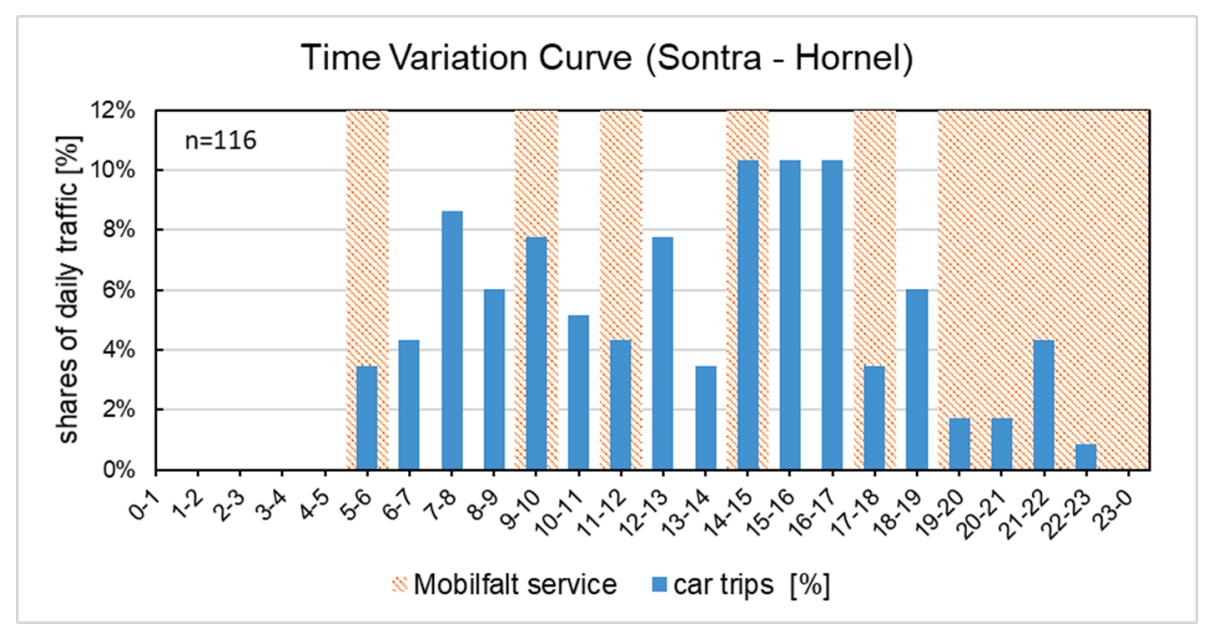

Fig. 5. Time variation curve of MPT trips on the relation between Sontra and Hornel in comparison with the Mobilfalt service.

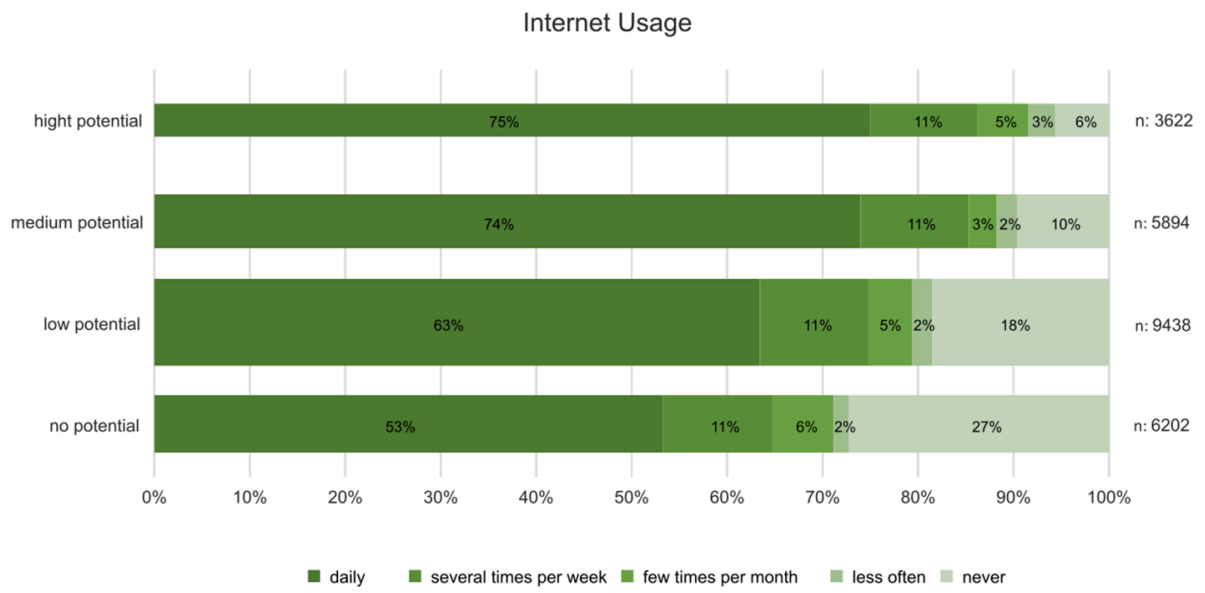

Fig. 6. Allocation of the potential groups (drivers) into frequency of internet usage. Source: Sommer and Harz (2018).

timetable was implemented with an expansion of departure options by offering a 10-minute interval for Mobilfalt trips. This led to an increase in the share of private rides. For example, the highest share of private trips was achieved in Witzenhausen in November 2017 (4.2\%), February 2018 (3.3\%) and April 2018 (3.1\%). It is worth noting that an integrated ridesharing system with a private driver share of $5.3 \%$ or more leads to higher cost recovery than a comparable flexible form of service with an IT-supported background system. (Schmitt, 2020)

\subsection{Organization of shared rides}

The analysis of potential for participation in Mobilfalt made it possible to differentiate more precisely between people with a high potential as drivers or passengers according to sociodemographic and behavioral variables (Sommer and Harz, 2018). It was shown that highly mobile people with a high internet affinity in particular have a great potential to become active as drivers (see Fig. 6). For these groups of people, out-of-home activities and the related trips take up a great deal of their time in everyday life. Both the time and effort required to organize and arrange ridesharing trips should therefore be as low as possible. The processes should be very simple and quick, especially for potential drivers. Due to the disproportionately high internet affinity of the target group, it is advisable to support the users via mobile applications and thus simplify the processes.

\subsection{Integration of shared rides into public transport marketing processes}

The ex-post user survey investigated how the passengers surveyed had learned about Mobilfalt before they registered. The survey showed that $35 \%$ of the passengers learned about Mobilfalt from acquaintances and $27 \%$ from online travel information and notices at public transportation stops. On the other hand, only $22 \%$ of passengers were acquainted with Mobilfalt through traditional communication measures. Existing public transport communication channels obviously have a greater impact on the awareness of passengers than their own classic communication campaigns.

The partial integration of Mobilfalt into the existing public transport tariff was linked with a distinction between private rides and rides with the mobility guarantee. This meant that for users without a transit pass, rides became more expensive. Fears that this would lead to falling passenger numbers were baseless. Even though, existing tickets are by now valid for Mobilfalt, users still need to book rides via the Mobilfalt booking system. A full integration on the level of distribution would mean that the booking process could be done through the usual distribution channels of the public transport agency, especially through mobile apps.

Overall, it is fair to say that integrating ridesharing into public transport at all four levels (transport offer, distribution, fare, and information/communication) can facilitate integrated use, reduce access barriers for customers and increase the visibility of both services. 


\section{Conclusions}

During the research, it became clear that the adaptability of the booking system is important for making it attractive to offer rides. Due to limitations of the Mobilfalt booking system a full flexibilization was not possible. Instead, it was achieved indirectly through a 10-minute interval of rides. In addition, other technical adjustments of the Mobilfalt backend were limited due to the start of the system in 2013 and nonexiting App-support. For future ridesharing projects, it is important, that the underlying background system allows flexible ridesharing offers and integration into mobile apps.

The continuous inspection of the Mobilfalt usage data showed, that a matching between a private driver and a passenger often worked, when the driver and the passenger arrived with the same train at the local train station and when the driver offered his car ride home at Mobilfalt. It would be interesting to know, especially for future projects and research, how pooling of commuters by train schedules can help to conciliate short distance ridesharing trips.

The findings illustrate how ridesharing as part of an integrated public transport system can increase mobility options in rural areas. The focus should be on attracting active drivers and increasing the proportion of private rides by addressing the needs of drivers in terms of functionality, processes and operation. At the same time, a mobility guarantee is imperative in order to create reliability for passengers and thus increasing social participation, especially for those who do not have access to a car. The coherences between different properties of a trip like the trip purpose, user groups and reliability are worth to examine in future research.

An integration of ridesharing into existing public transport structures allows continuous trip chains with a coherent tariff and booking system, which can be used by everybody. An integrated ridesharing system with a mobility guarantee can already be operated with low shares of rides by private drivers and is thereby cheaper than flexible forms of service with an IT-supported background system.

\section{Funding}

The research project "GetMobil", which this paper is based on, has been financed by the German Federal Ministry for Education and Research (grant number 01UT1402A).

\section{Miscellaneous}

An earlier version of this paper was submitted and accepted to the Transport Research Arena 2020 in Helsinki (cancelled due to COVID19).

\section{CRediT authorship contribution statement}

Jonas Harz: Conceptualization, Methodology, Formal analysis, Investigation, Writing - original draft, Writing - review \& editing. Carsten Sommer: Conceptualization, Methodology, Writing - review \& editing, Supervision.

\section{Declaration of Competing Interest}

The authors declare that they have no known competing financial interests or personal relationships that could have appeared to influence the work reported in this paper.

\section{References}

Ambrosino, G., 2018. Shared Use Mobility Agency in Elba island: from the concept to the IT Platform. https://civitas.eu/sites/default/files/shared-use-mobility-agency_boo klet.pdf (accessed 30 July 2021).
Artho, J., Haefeli, U., Matti. Daniel, 2005. Evaluation Pilotprojekt CARLOS, 28 pp. https ://www.mobilservice.ch/admin/data/files/news_section_file/file/1343/synthes ebericht-liegt-nun-vor.pdf? $1 \mathrm{~m}=1418801107$ (accessed 17 August 2021).

Becker, J., Blees, V., Hasenstab, M., Freyer, L., Löw, G., 2019. Erfolgsfaktor Mitfahrbank?!: Wissenschaftliche Untersuchung der Akzeptanz und des Nutzens von Mitfahrbänken. Schlussbericht. Fachzentrum für Mobilität im ländlichen Raum des Landes Hessen, Frankfurt am Main, Wiesbaden. https://www.frankfurt-university. de/fileadmin/standard/Hochschule/Fachbereich_1/FFin/Neue_Mobilitaet/Veroeff entlichungen/2020/Schlussbericht_Mitfahrbaenke_19-12-09.pdf (accessed 17 August 2021).

Benz, H., Kepper, J., 2019. Realexperiment: Maßnahmen für Mobilfalt, in: Daskalakis, M., Sommer, C., Roßnagel, A. (Eds.), Ländliche Mobilität vernetzen: Ridesharing im ländlichen Raum und dessen Integration in den öffentlichen Nahverkehr. oekom Verlag, München, pp. 353-358.

Çetin, T., 2017. The Rise of Ride Sharing in Urban Transport: Threat or Opportunity?, in: Yaghoubi, H. (Ed.), Urban Transport Systems. InTech, pp. 191-202.

Chan, N.D., Shaheen, S.A., 2012. Ridesharing in North America: Past, Present, and Future. Transport Reviews 32, 93-112. https://doi.org/10.1080/ 01441647.2011 .621557$.

Daskalakis, M., 2019. Teilnahmebereitschaft an lokalen, organisierten RidesharingAngeboten - Eine Analyse aus verhaltensökonomischer Perspektive. In: Daskalakis, M., Sommer, C., Roßnagel, A. (Eds.), Ländliche Mobilität vernetzen: Ridesharing im ländlichen Raum und dessen Integration in den öffentlichen Nahverkehr. oekom Verlag, München, pp. 91-188.

Follmer, R., Gruschwitz, D., 2019. Mobility in Germany - Short report: Edition 4.0 of the study by infas, DLR, IVT and infas 360 on behalf of the Federal Ministry of Transport and Digital Infrastructure, 32 pp. https://www.bmvi.de/SharedDocs/DE/Anlage /G/mid-2017-short-report.pdf?_blob=publicationFile (accessed 17 August 2021).

Furuhata, M., Dessouky, M., Ordóñez, F., Brunet, M.-E., Wang, X., Koenig, S., 2013. Ridesharing: The state-of-the-art and future directions. Transportation Research Part B: Methodological 57, 28-46. https://doi.org/10.1016/j.trb.2013.08.012.

German Federal Ministry of Transport and Digital Infrastructure, 2016. Mobilitäts- und Angebotsstrategien in ländlichen Räumen: Planungsleitfaden für Handlungsmöglichkeiten von ÖPNV-Aufgabenträgern und Verkehrsunternehmen unter besonderer Berücksichtigung wirtschaftlicher Aspekte flexibler Bedienungsformen. Bundesministerium für Verkehr und digitale Infrastruktur, Berlin https://www.bmvi.de/SharedDocs/DE/Publikationen/G/mobilitaets-undangebotsstrategien-in-laendlichen-raeumen-neu.pdf?_blob=publicationFile (accessed 17 August 2021).

Harz, J., Sommer, C., 2019. Systemanalyse flinc, in: Daskalakis, M., Sommer, C., Roßnagel, A. (Eds.), Ländliche Mobilität vernetzen: Ridesharing im ländlichen Raum und dessen Integration in den öffentlichen Nahverkehr. oekom Verlag, München, pp. 260-290.

Krämer, P., Weiß, A., Benz, H., 2019. Vernetzung aller Mobilitätsangebote. Der Nahverkehr 2019, 52-57.

Leuzinger, E., Meyer, B., 2017. Baden FahrMit / PubliRide Baden: Mitfahrnetzwerk für die Region Baden. Kanton Aargau, Abteilung Verkehr https://pubdb.bfe.admin.ch/ de/publication/download/9651 (accessed 17 August 2021).

Osti, G., 2010. Mobility Demands and Participation in Remote Rural Areas. Sociologia Ruralis 50, 296-310. https://doi.org/10.1111/j.1467-9523.2010.00517.x.

Petersen, T., 2016. Watching the Swiss: A network approach to rural and exurban public transport. Transp. Policy 52, 175-185. https://doi.org/10.1016/j. tranpol.2016.07.012.

Pucher, J., Renne, J.L., 2005. Rural mobility and mode choice: Evidence from the 2001 National Household Travel Survey. Transportation 32, 165-186. https://doi.org/ 10.1007/s11116-004-5508-3.

Roubicek, M., 2019. Informelles Ridesharing durch Mitfahrbänke. Bachelor Thesis unpublished.

Schmitt, V., 2020. In den ÖPNV integrierte Mitnahmesysteme im ländlichen Raum Wirkungsanalyse und Bewertung. PhD thesis. kassel University Press GmbH, Kassel.

SMARTA, 2019. Rezopouce: Organizing modern hitch-hiking. https://ruralsharedmobilit y.eu/wp-content/uploads/2019/08/SMARTA-GP-Rezopouce.pdf (accessed 6 August 2021).

Sommer, C., Harz, J., 2018. Determination of Potentials for Drivers and Passengers of Integrated Ridesharing Services in Rural Areas. 7th Transport Research Arena TRA 2018, Vienna. https://doi.org/10.5281/zenodo.1440906.

Sommer, C., Mucha, E., Roßnagel, A., Anschütz, M., Hentschel, A., Loose, W., 2016. Umwelt- und Kostenvorteile ausgewählter innovativer Mobilitäts- und Verkehrskonzepte im städtischen Personenverkehr: Endbericht: Forschungskennzahl 371296101 UBA-FB 002419/1. Umweltforschungsplan des Bundesministeriums für Umwelt, Naturschutz, Bau und Reaktorsicherheit 87/2016. Bundesministerium für Umwelt, Naturschutz, Bau und Reaktorsicherheit, Dessau-Roßlau. https://www.um weltbundesamt.de/sites/default/files/medien/377/publikationen/2016-12-14_um komoko_endbericht1_fin.pdf (accessed 17 August 2021).

Sommer, C., Schmitt, V., 2015. Wissenschaftliche Begleitung und Evaluation des Projektes „Mobilität im ländlichen Raum / Mobilfalt“ (unpublished).

Steinrück, B., Küpper, P., 2010. Mobilität in ländlichen Räumen unter besonderer Berücksichtigung bedarfsgesteuerter Bedienformen des ÖPNV. https://literatur.thu enen.de/digbib_extern/bitv/dk043302.pdf (accessed 17 August 2021). 
Stiglic, M., Agatz, N., Savelsbergh, M., Gradisar, M., 2016. Enhancing Urban Mobility: Integrating Ride sharing and Public Transit. ERIM Report Series Research in Management. https://doi.org/10.1016/j.cor.2017.08.016.

Thao, V.T., Imhof, S., von Arx, W., 2021. Integration of ridesharing with public transport in rural Switzerland: Practice and outcomes. Transportation Research
Interdisciplinary Perspectives 10, 100340. https://doi.org/10.1016/j. trip.2021.100340.

Wegmann, A., 2007. Ridesharing in den USA, Kanada, Neuseeland und Europa bis 2007. https://www.are.admin.ch/dam/are/it/dokumente/verkehr/dokumente/bericht/r ms ridesharing indenusakanadaneuseelandundeuropa.pdf.download.pdf/rms_ride sharing_indenusakanadaneuseelandundeuropa.pdf (accessed 17 August 2021). 